\title{
Heterotrimeric G Protein
}

National Cancer Institute

\section{Source}

National Cancer Institute. Heterotrimeric G Protein. NCI Thesaurus. Code C18281.

Heterotrimeric guanine nucleotide-binding proteins ( $G$ proteins) are signal transducers, attached to the cell surface plasma membrane, that connect receptors to effectors and thus to intracellular signaling pathways (1). Receptors that couple to $\mathrm{G}$ proteins communicate signals from a large number of hormones, neurotransmitters, chemokines, and autocrine and paracrine factors. After the first four G proteins (Gs, Gt, $\mathrm{Gi}$, and $\mathrm{Go}$ ) were identified by biochemical purification, a large number of $\mathrm{G}$ proteins and their subunits were identified by cDNA cloning (2). G proteins consist of three subunits, alpha, beta, and gamma. When signaling, they function in essence as dimers because the signal is communicated either by the Ga subunit or the Gbg complex. In most cases, Gbg subunits cannot be dissociated under nondenaturing conditions. Currently there are 20 known G, 6 G, and 11 G subunits. (from Science 2002;296:1636-9) 